\title{
THE EFFECT OF ELECTROSTATIC ACTIVATION PARAMETERS ON THE RHEOLOGIC AND STRENGTH PROPERTIES OF FINE-GRAINED CONCRETE
}

\author{
Nickolay Zaichenko, Nickolay Golodenko, Alexander Khalyushev \\ Donbass National Academy of Civil Engineering and Architecture, \\ Dergavin st. 2, Makeevka, Donetsk reg., Ukraine.E-mail: mvf@dgasa.dn.ua \\ Received 25 Jan 2007; accepted 21 May 2007
}

\begin{abstract}
The use of supplementary materials (limestone or pozzolans) as partial replacement of Portland cement to obtain a high-performance concrete has received considerable attention in recent years. However, these materials suffer from some shortcomings - limestone filler addition causes an increase of hydration at early ages but it can reduce the later strength due to the dilution effect, fly-ash improves the concrete strength at later ages. To eliminate this problem the method of activation of Portland cement and fillers in electrostatic-corona field has been developed. By the optimal activation parameters the rheological properties of concrete mixtures as well as concrete strength are increased.
\end{abstract}

Keywords: activation, corona-electrostatic field, concrete, viscosity, compressive strength, fly-ash, limestone.

\section{Introduction}

Concrete is probably the most extensively used construction material in the world. This is largely due to the abundance of raw materials for cement and concrete manufacture as well as low relative cost [1]. On the other hand, modern concretes are more than simply mixtures of cement, water and aggregates. They contain more and more often mineral components having very specific characteristics that give specific properties to concrete [2].

Interaction between various materials can cause wide variations in workability, which also depends on the specific materials and proportions used. It's a matter of common knowledge that the addition of mineral additives reduces fresh concrete workability, when the volume concentration of a solid phase is held constant. The most common reason is that fine mineral particles increase the water demand due to the increase in surface area [3]. However, in certain cases the use of fine mineral additives can reduce the water demand or increase concrete workability. For example, fine carbonate or fly-ash fillers complement the deficiency in fine particles of the cement particle size distribution, which can enhance both the flowability and stability of fresh concrete [4].

On the other hand, these supplementary materials suffer from some shortcomings. Thus limestone filler addition as a partial replacement of Portland cement causes an increase of hydration at early ages inducing a high-early strength, but it can reduce the later strength due to the dilution effect [5]. As for fly-ash, it contributes to hydration after a certain period improving the concrete strength at later ages [6]. To eliminate this problem many studies on activation mineral fillers with various kinds of special treatment such as mechanical grinding, thermal and chemical activation etc have been conducted [7].
Different electrophysics activation methods are used less often. It has been established earlier that a highvoltage electrostatic polarisation of Portland cement causes acceleration of its hydration and intensifies cement paste structuring $[8,9]$. It is confirmed by the calorimetric researches of thermal emission kinetics on the initial ages of hardening different minerals of clinker and Portland cement [9]. Accumulation of electric charges on the surface of cement dispersion particles caused by their electrostatic polarisation must influence interparticle interactions in cement paste stipulating its rheological properties and strength characteristics of the concrete.

The method of electrostatic treatment of cement and the installation for activation have been developed earlier [10]. At the same time, the regimes of electrostatic treatment as well as the geometrical parameters of installation were not substantiated. This is because the electrostatic field strength achieves the maximum value near the corona electrode and decreases with an increase of the distance from it. A computer modelling of the coronaelectrostatic field to optimise the installation for activating dispersed materials in the corona-electrostatic field has been carried out.

\section{Computer modelling of electrostatic activation}

Electrostatic field of a rectilinear wire (cross-section radius $a$ ) coaxial with a grounded tubular metallic cylinder (radius $R$ ) is described by the formulas:

$$
\begin{gathered}
\int_{S} \boldsymbol{E}_{0} d \boldsymbol{S}=\tau h / \varepsilon_{0} ; 2 \pi r h E_{0}=\tau h / \varepsilon_{0} ; \quad E_{0}=\tau /\left(2 \pi r \varepsilon_{0}\right), \\
U=\int_{a}^{R} E_{0} d r=\frac{\tau}{2 \pi \varepsilon_{0}} \ln \frac{R}{a},
\end{gathered}
$$




$$
\begin{gathered}
V_{0}=\int_{r}^{R} E_{0} d r=\frac{\tau}{2 \pi \varepsilon_{0}} \ln \frac{R}{a} \cdot \frac{\ln (R / r)}{\ln (R / a)}=\frac{U \ln (R / r)}{\ln (R / a)}, \\
\vec{E}=-\nabla V, \\
E_{0}=-\frac{d V_{0}}{d r}=\frac{U / r}{\ln (R / a)},
\end{gathered}
$$

where $E_{0}$ is the electrostatic field strength at the wire surface, $S$ - the area surface, $\tau$ - the electric charge linear density, $h$ - the wire length, $\varepsilon_{0}=8,85 \cdot 10^{-12} \mathrm{~F} / \mathrm{m}$ the electric constant, $r-$ a distance from the cylinder axis, $U-$ the wire potential, $V_{0}$ - electrostatic field potential at the distance $r$ from the cylinder axis.

Corona interception field strength at the surface of the wire electrode in air at atmospheric pressure in accordance with Peek's law (Kaptzov's assumption [11]) is

$$
E_{a}=k_{1}\left(1+k_{2} / \sqrt{a}\right),
$$

where $k_{1}=30,1 \cdot 10^{5} \mathrm{~V} / \mathrm{m}, \quad k_{2}=0,0301 \mathrm{~m}^{1 / 2}$. The mathematical model of corona-electrostatic fields has been derived under the following assumptions [12]:

- thickness of the ionisation zone is negligible;

- the drift zone of the corona contains only unipolar ions;

- thermal diffusion and recombination of ions are negligible;

- ion mobility is constant.

Current density in the gas discharge:

$$
j=q n b E=\rho b E,
$$

where $q$ is ion charge, $n-$ ion concentration, $E-$ corona-electrostatic field strength, $\rho$ - space charge density, $b$ - ion mobility:

$$
\begin{aligned}
& b_{+}=1,4 \cdot 10^{-4} \mathrm{~m}^{2} /(\mathrm{V} \cdot \mathrm{s}), \\
& b_{-}=1,9 \cdot 10^{-4} \mathrm{~m}^{2} /(\mathrm{V} \cdot \mathrm{s}) .
\end{aligned}
$$

The space charge density at the wire surface:

$$
\rho_{a}=i /\left(2 \pi a b E_{a}\right),
$$

where $i$ is the value of the corona current per unit of electrode length. The space charge density $\rho$ is to satisfy the conservation equation:

$$
(\delta \rho / \delta t)+\nabla j=0 .
$$

In accordance with the Poisson's equation:

$$
\nabla \vec{E}=\rho / \varepsilon_{0} .
$$

From (1) and (4):

$$
\Delta V=-\rho / \varepsilon_{0} .
$$

Cylindrical symmetry gives:

$$
\Delta V=\frac{1}{r} \cdot \frac{\partial V}{\partial r}+\frac{\partial^{2} V}{\partial r^{2}} .
$$

From (3), (2), (4) and (1):

$$
\begin{gathered}
(\delta \rho / \delta t)+\nabla(\rho b \vec{E})=0, \\
(\delta \rho / \delta t)+b \rho \nabla \vec{E}+b \vec{E} \nabla \rho=0 .
\end{gathered}
$$

We must solve the iterative system of equations received from (6), (5) and (1):

$$
\begin{gathered}
\left(\rho_{m, n, k}-\rho_{m, n-1, k}\right) / t_{\mathrm{s}}+b \rho_{m-1, n, k} \rho_{m, n, k} / \varepsilon_{0}+ \\
b E_{m-1, n, k}\left(\rho_{m, n, k}-\rho_{m, n, k-1}\right) / r_{\mathrm{s}}=0, \\
\left(V_{m, n, k-1}-V_{m, n, k-2}\right) / r_{\mathrm{s}} / r_{k}+\left[\left(V_{m, n, k}-V_{m, n, k-1}\right)-\right. \\
\left.\left(V_{m, n, k-1}-V_{m, n, k-2}\right)\right] / r_{\mathrm{s}}^{2}=-\rho_{m, n, k-1} / \varepsilon_{0}, \\
E_{m, n, k}=\left(V_{m, n, k-1}-V_{m, n, k}\right) / r_{\mathrm{s}},
\end{gathered}
$$

where $m$ denotes the iteration at a fixed time $t=n t_{\mathrm{s}}, t_{\mathrm{s}}$ is the time step, $r_{\mathrm{s}}=(R-a) / K-$ the space step, $r_{k}=a+k r_{\mathrm{s}}$, $K-$ the space step quantity. From (7) and (8):

$$
\begin{gathered}
\rho_{m, n, k}=\frac{\rho_{m, n-1, k} r_{\mathrm{s}}+\rho_{m, n, k-1} b t_{\mathrm{s}} E_{m-1, n, k}}{r_{\mathrm{s}}+b \rho_{m-1, n, k} t_{\mathrm{s}} r_{\mathrm{s}} / \varepsilon_{0}+b t_{\mathrm{s}} E_{m-1, n, k}}, \\
V_{m, n, k}=V_{m, n, k-1}\left(2-\frac{r_{\mathrm{s}}}{r_{k}}\right)-V_{m, n, k-2}\left(1-\frac{r_{s}}{r_{k}}\right)-\frac{q_{m, n, k-1} r_{\mathrm{s}}^{2}}{\varepsilon_{0}} .
\end{gathered}
$$

The initial conditions are

$$
\begin{gathered}
\rho_{0,0,0}=\rho_{a} ; \quad \rho_{0,0, k>0}=0, \\
V_{0,0, k}=\frac{U \ln \left(R / r_{k}\right)}{\ln (R / a)}, \\
E_{0,0,0}=E_{a} ; \quad E_{0,0, k}=\frac{U / r_{k}}{\ln (R / a)} .
\end{gathered}
$$

The boundary conditions are

$$
V_{m, n, 0}=U, \quad V_{m, n, K}=0, E_{m, n, 0}=E_{a} .
$$

Computation has shown that the combined coronaelectrostatic field was settled in less than $1 \mathrm{~ms}$. It follows that the electrodes can be fed by the voltage of industrial frequency. At the wire cross-section diameter $d=0,6 \mathrm{~mm}$, cylinder diameter $D=100 \mathrm{~mm}$, wire potential $U=-25 \mathrm{kV}$ and corona current per unit of electrode length $i=0,5 \mathrm{~mA} / \mathrm{m}$ space charge density near the wire was $170 \mu \mathrm{C} / \mathrm{m}^{3}\left(10^{6}\right.$ single-charge ions in $\left.1 \mathrm{~mm}^{3}\right)$. Near the grounded cylinder surface it was approx 4 times less remaining big enough (Fig 1). Thus the accepted parameters meet the requirements. They allow creating the sufficient concentration of ions in all volume of the

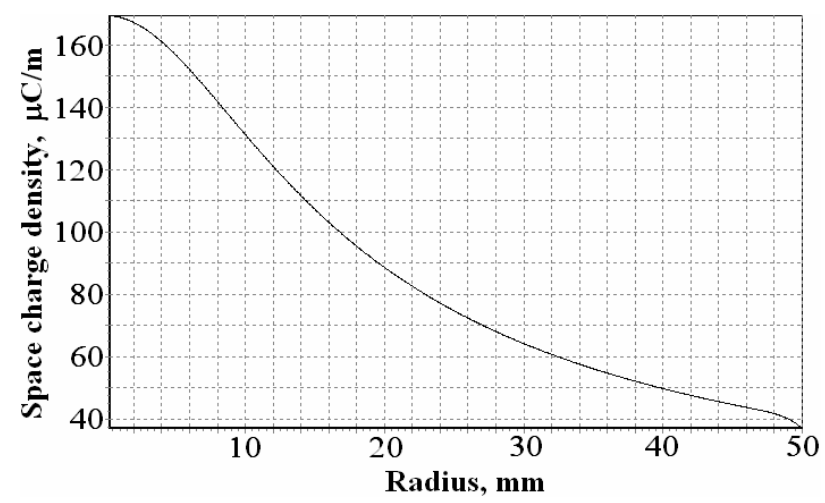

Fig 1. Computed ion space charge density distribution along the radius in the combined corona-electrostatic field 
activation chamber. Potential leap at the grounded metallic cylinder is conditioned by the fact that the ion space charge causes acceleration of ions and decreases their concentration.

\section{Materials and experimental methods}

The cement used was a milled Portland clinker with a Blaine fineness $320 \mathrm{~m}^{2} / \mathrm{kg}$. Its phase composition is given in Table 1. Fly-ash and milled limestone were added as dry powders (fillers). The fly-ash and milled limestone employed in these experiments had a specific surface of $210 \mathrm{~m}^{2} / \mathrm{kg}$ and $535 \mathrm{~m}^{2} / \mathrm{kg}$ accordingly. Plasticiser (cement set retarder) was added at a rate of $0,3 \%$ by mass of cement + filler (when the viscosity of concrete mixtures was measured). The plasticiser was a lignosulfonate-based dry powder. A superplasticiser based on modified polycarboxylic ether (FM-34 from Addiment) was used as a high range water reducer (when the concrete strength was measured). The dosage of HRWR was $0,75 \%$ solid by mass of cementitious materials.

Two types of fine aggregate (quartz sand with the fineness modulus of 1,5 , packing density $1470 \mathrm{~kg} / \mathrm{m}^{3}$, apparent density $2675 \mathrm{~kg} / \mathrm{m}^{3}$ and granite crushed stone with maximum size of $5 \mathrm{~mm}$, packing density $1485 \mathrm{~kg} / \mathrm{m}^{3}$, apparent density $2715 \mathrm{~kg} / \mathrm{m}^{3}$ ) were used in concrete composition. The mixture of the two fine aggregates was made of 60 and $40 \%$ accordingly.

Table 1. Phase composition of Portland cement clinker

\begin{tabular}{l|c}
\hline Phase & Mass \% \\
\hline $\mathrm{C}_{3} \mathrm{~S}$ & 57,4 \\
$\mathrm{C}_{2} \mathrm{C}$ & 27,9 \\
$\mathrm{C}_{3} \mathrm{~A}$ & 5,1 \\
$\mathrm{C}_{4} \mathrm{AF}$ & 9,6 \\
\hline
\end{tabular}

Dispersed fillers and Portland cement were activated on the specially constructed installation which functioned on the principle of a corona electro-filter (Fig 2). The corona electrode - a copper wire with a diameter of $0,6 \mathrm{~mm}$ was coaxial with the grounded metallic tube. Materials were treated at the electric field strength $E=20-15 \mathrm{kV} / \mathrm{cm}$ and the current intensity $I=25-40 \mu \mathrm{A}$.

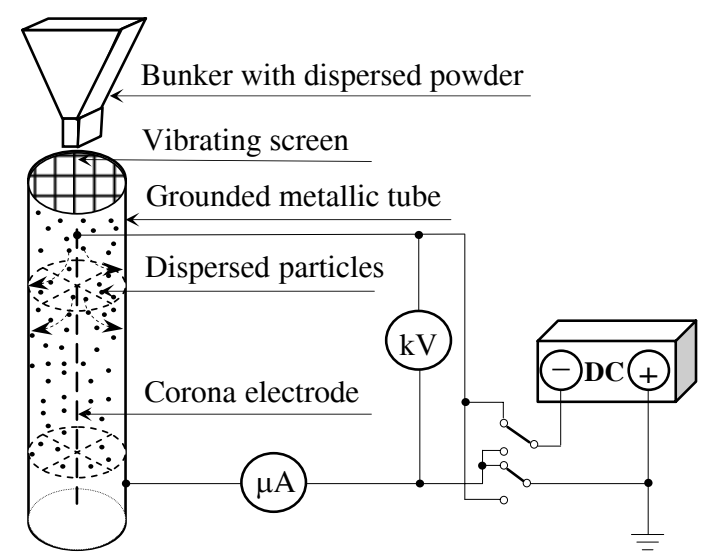

Fig 2. Installation for dispersed materials activation in the corona-electrostatic field
Interparticle interactions in the dispersed system were estimated by kinetics of hard phase (filler) settling in a liquid environment (water). A measuring glass cylinder with volume $1 l$ filled on 2/3 with distilled water with $\mathrm{pH}=6,5$ was used in the experiment. Powdery material was poured gradually into the cylinder. Stirring with a glass stick eliminated the rapid settling of particles and formation of sediment. Then the cylinder was refilled with water to the definite mark and the content of the cylinder was shaken up. After some time a hard phase separates from the liquid and settles under the action of gravity. The volume of appearing sediment was determined at stated intervals.

The viscosimeter used for rheological measurements of the concrete mixtures was a ball vibration viscosimeter (Fig 3). It is the simplest, accessible and widespread device for measuring viscosity of concrete mixtures during vibration [13, 14]. The effective viscosity of concrete mixtures was determined by an equation [13]

$$
\eta_{v}=\frac{2}{6 \pi r v}\left[M g+\frac{4}{3} \pi r^{3} g\left(\rho_{\mathrm{c}}-\rho_{\mathrm{b}}\right)-\frac{m}{2 l} v^{2}\right],
$$

where $M$ is the weight of an additional load [kg], $m-$ the ball weight [kg], $r$ - the ball radius [m], $v-$ the ball float speed on the boundary of measuring distance $[\mathrm{m} / \mathrm{s}], \rho_{c}$ and $\rho_{b}$ are the densities of concrete mixture and material of the ball $\left[\mathrm{kg} / \mathrm{m}^{3}\right]$.
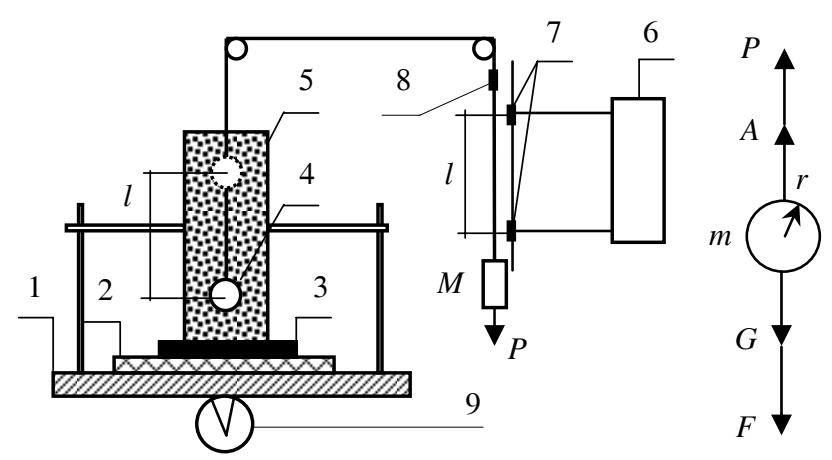

Fig 3. Installation for rheological measurements of concrete mixtures: 1 - vibration platform, 2 - removable bottom of cylinder, 3 - rubber insert, 4 - lead ball, 5 cylinder, 6 - electronic timer, 7 - hercon sensor, 8 - magnet, 9 - vibrator

The ball in viscosimeter is floating up under the action of vibration and load by mass $M$ with the speed $v$ on the measured distance in the column of concrete mixture $l=100 \mathrm{~mm}$. The ball with a radius $r=24 \mathrm{~mm} \mathrm{(4,8} \mathrm{times}$ more than a conventional radius of aggregate particle) is plumbic in order to avoid the influence of the magnetic field. The ball is affected by its weight $G$, the force of tension of the thread from the additional load $P$, the Archimedean force $A$ and the Stokes' force $F$. The latter is expressed through the speed of floating up of the ball on the measured distance of the concrete mixture column and the coefficient of dynamic viscosity $\eta_{v}$ [13]. The duration of floating up is fixed by the electronic timing device to an accuracy of $\pm 0,1 \mathrm{~s}$. 
In the present investigation this method has been used to estimate the relative differences in rheological parameter (viscosity) of different concrete mixtures (with treated and untreated dispersed components). In this case the calibration of rheometer was considered unnecessary. The flow table was used for workability measurements of the concrete mixtures (Fig 4).

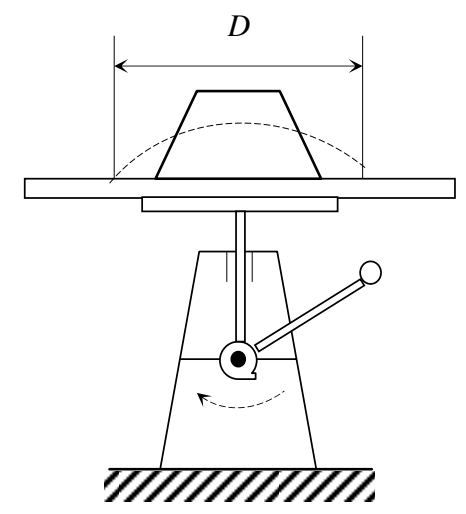

Fig 4. Flow table for determining the workability of freshly mixed concrete

\section{Results and discussion}

The results obtained after the analysis of the kinetic of sedimentation of mineral dispersed systems are reported in Fig 5, in which the volume of sediment $V_{s}$ as a function of the duration of sedimentation $\tau_{s}$ has been plotted (the relative error is $1,5-1,8 \%$ at the confidence level $95 \%$ ). Mineral fillers and Portland cement were preliminary processed in the installation for electrostatic activation. The materials were activated at different polarity of the corona electrode taking into account their superficial charge. It is known [15] that fly-ash has the negative superficial charge and Portland cement clinker and limestone have a positive one.

Treatment of fly-ash in the corona field causes intensification of sedimentation of ash suspension in comparison with the control specimen (Fig 5a). It is observed both with negative and positive corona electrode polarity. The most intensive of fly-ash suspension was taking place within the first $25 \mathrm{~min}$ with a further stabilisation of the sediment volume, which size for activated fly-ash was found to be $5,5 \%$ less in comparison with the control specimen. Kinetic sedimentation curves for mineral dispersions on the base of milled limestone filler (Fig 5b) have approximately the same character.

If mineral dispersed system is presented by the mixture of Portland cement clinker with filler (20\% from the mass of cement), sedimentation of particles passes more intensively. This process is considerably accelerated in case of the bipolar electrostatic polarisation of cement and mineral filler particles. The size of sediment volume for mineral dispersed systems with activated Portland cement (negative corona electrode polarity) and fly-ash or milled limestone (positive) was found to be $8,2 \%$ and $8,7 \%$ less in comparison with the control specimen accordingly (Fig 5c, d). Owing to the Coulomb interaction the electro-heterogeneous contacts appear between the oppositely charged particles. It results in enlargement of particles and speeding-up of their settling. The volume of appearing sediment diminishes. Syneresis is taking place in the dispersed system in consequence of the change of the balance of interparticle interaction forces. This phenomenon is conditioned by the extrusion of surplus water adsorbed by the surface of solid particles. It must provide the improvement of workability of cement pastes and concrete mixtures.

The effective viscosity (the viscosity during vibration) was explored for the fine-grained concrete mixtures with Portland cement : quartz sand $=1: 3$ composition. Fly-ash and milled limestone were used as fillers $(20 \%$ from the mass of cement). A plasticising admixture (lignosulphonate) was used to remove the influencing of cement paste structuring on the indexes of effective viscosity of concrete mixtures. This additive was slowing down the hardening of the cement paste. The ratio water: cement for all explored compositions was permanent - 0.40. Data reported (Fig 6) represent the average effective viscosity values obtained on 3 specimens for each composition of concrete mixtures. The relative error is in the range of $5,7-6,6 \%$ (at the confidence level $95 \%$ ).

It is ascertained that a partial replacement of Portland cement by fly-ash or limestone filler causes the rise of the effective viscosity of the system. For a concrete mixture with addition of limestone it is related to the rise of specific surface of hard phase particles [4]. Fly-ash is characterised by a larger granulometric composition in comparison with Portland cement. At the same time a presence of not burned out coal particles in the fly-ash raises the water consumption of concrete mixture, causing the decline of its workability [16].

The unipolar charging of cement and mineral additives causes an insignificant decline in indexes of effective viscosity of concrete mixtures. It is related to the electrostatic repulsion between uniformly charged particles, that causes stabilisation of the system. At the same time in case of bipolar treatment of dispersed components of concrete mixtures their effective viscosity is by $1,36-$ 1,4 times less in comparison with control compositions. This effect is conditioned by aggregation of the differently charged particles of cement and mineral additives and as a result declination of specific surface of dispersed particles. The surplus water in the system causes its plasticisation.

The modification of adhesive contacts on the boundary of cement paste - mineral filler will promote the formation of a more homogeneous and dense microstructure of fine-grained concrete [17]. The concrete will have higher physical-mechanical properties as a result [18]. On the other hand, the established effect of concrete mixture plasticising (declining of effective viscosity) due to the high voltage electrostatic treatment of powder materials allows to decrease their water demand, while the required workability is saved. That provides an additional increase of concrete strength.

To establish the influence of the electrostatic treatment of concrete dispersed components on the indexes of 


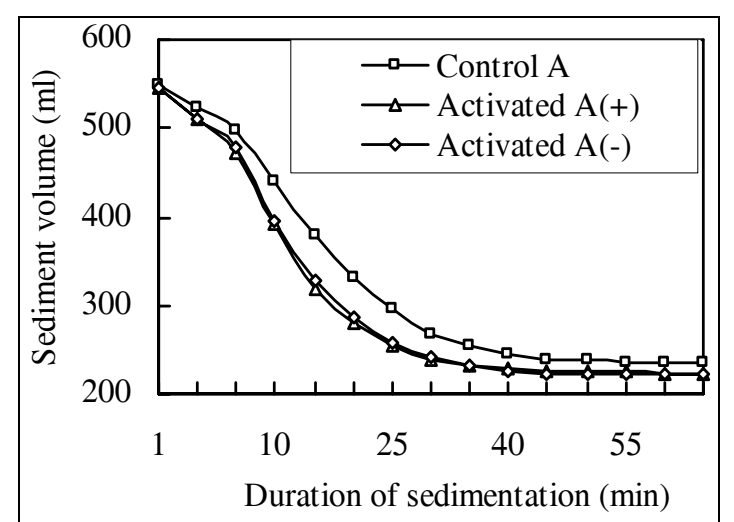

a)

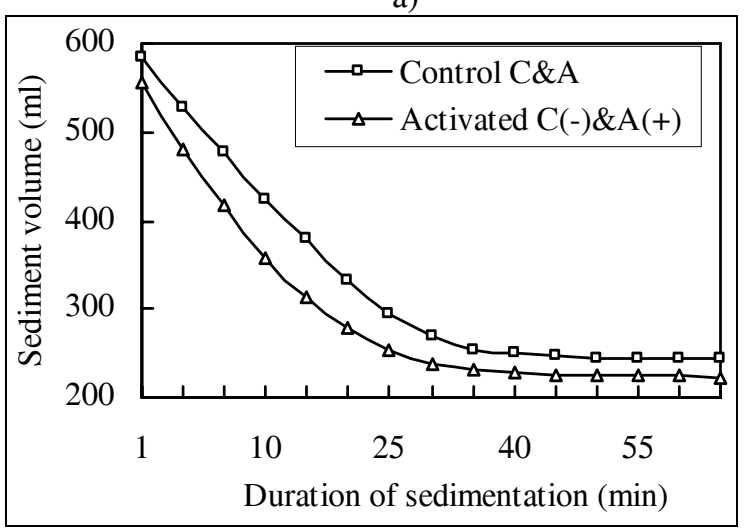

c)

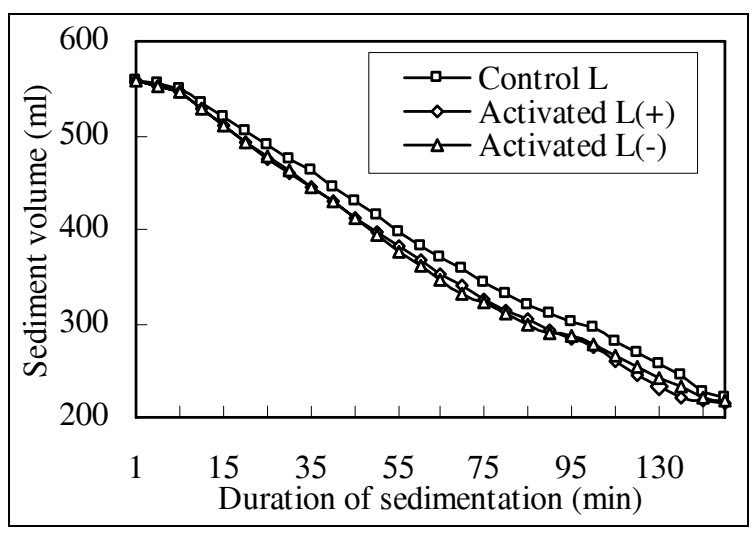

b)

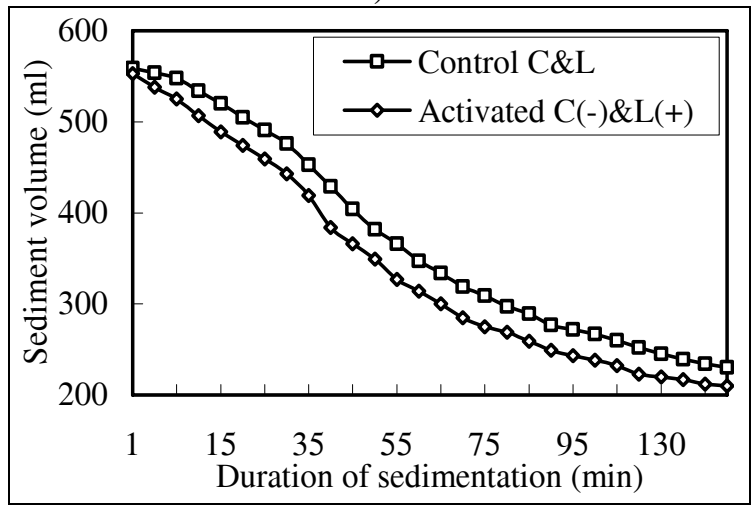

d)

Fig 5. Kinetic of sedimentation of mineral dispersed system $(\mathrm{C}-$ cement, $\mathrm{A}-\mathrm{ash}, \mathrm{L}-$ limestone, $(+)-$ activation in positive corona field, $(-)$ - the same in negative corona field)

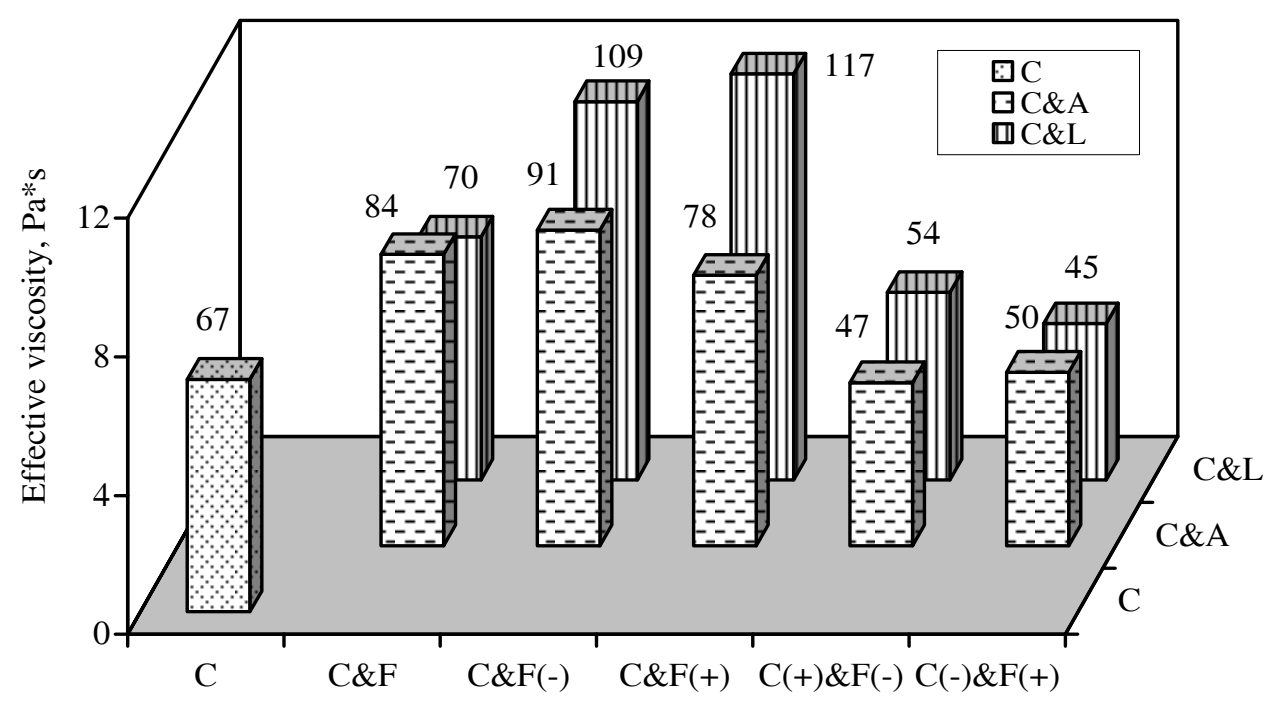

$\mathrm{C}$ - cement, $\mathrm{F}-$ filler $(\mathrm{A}$-ash, $\mathrm{L}-$ imestone $),(+)-$ activation in positive corona field, $(-)-$ the same in negative corona field

Fig 6. Effective viscosity of concrete mixtures 
Table 2. Mixture proportions

\begin{tabular}{|c|c|c|c|c|c|c|c|c|c|c|c|}
\hline \multirow{4}{*}{$\begin{array}{l}\text { Cement, } \mathrm{kg} / \mathrm{m}^{3} \\
\text { Fly-ash, } \mathrm{kg} / \mathrm{m}^{3} \\
\end{array}$} & \multirow{4}{*}{\begin{tabular}{c|}
$\mathrm{C}$ \\
750 \\
-
\end{tabular}} & & & & & & & & & & \\
\hline & & \multicolumn{2}{|c|}{$\mathrm{C} \& \mathrm{~F}$} & \multicolumn{2}{|c|}{$\mathrm{C} \& \mathrm{~F}(-)$} & \multicolumn{2}{|c|}{$\mathrm{C} \& \mathrm{~F}(+)$} & \multicolumn{2}{|c|}{$\mathrm{C}(+) \& \mathrm{~F}(-)$} & \multicolumn{2}{|c|}{$\mathrm{C}(-) \& \mathrm{~F}(+)$} \\
\hline & & \multicolumn{2}{|c|}{600} & \multicolumn{2}{|c|}{600} & \multicolumn{2}{|c|}{600} & \multicolumn{2}{|c|}{600} & \multicolumn{2}{|c|}{600} \\
\hline & & 150 & -- & 150 & - & 150 & - & 150 & - & 150 & - \\
\hline Milled limestone, $\mathrm{kg} / \mathrm{m}^{3}$ & - & - & 150 & - & 150 & - & 150 & - & 150 & - & 150 \\
\hline Quartz sand, $\mathrm{kg} / \mathrm{m}^{3}$ & \multicolumn{11}{|c|}{894} \\
\hline Crushed granite, $\mathrm{kg} / \mathrm{m}^{3}$ & \multicolumn{11}{|c|}{596} \\
\hline Water/cement, $\mathrm{kg} / \mathrm{kg}$ & 0,26 & 0,36 & 0,35 & 0,36 & 0,36 & 0,34 & 0,36 & 0,31 & 0,33 & 0,31 & 0,31 \\
\hline Superplasticiser FM-34, \% & \multicolumn{11}{|c|}{0,75} \\
\hline Water/powder materials, $\mathrm{kg} / \mathrm{kg}$ & 0,26 & 0,29 & 0,28 & 0,29 & 0,29 & 0,27 & 0,29 & 0,25 & 0,26 & 0,25 & 0,25 \\
\hline Cone running diameter, $\mathrm{mm}$ & 125 & 123 & 121 & 122 & 120 & 122 & 120 & 123 & 122 & 124 & 125 \\
\hline
\end{tabular}

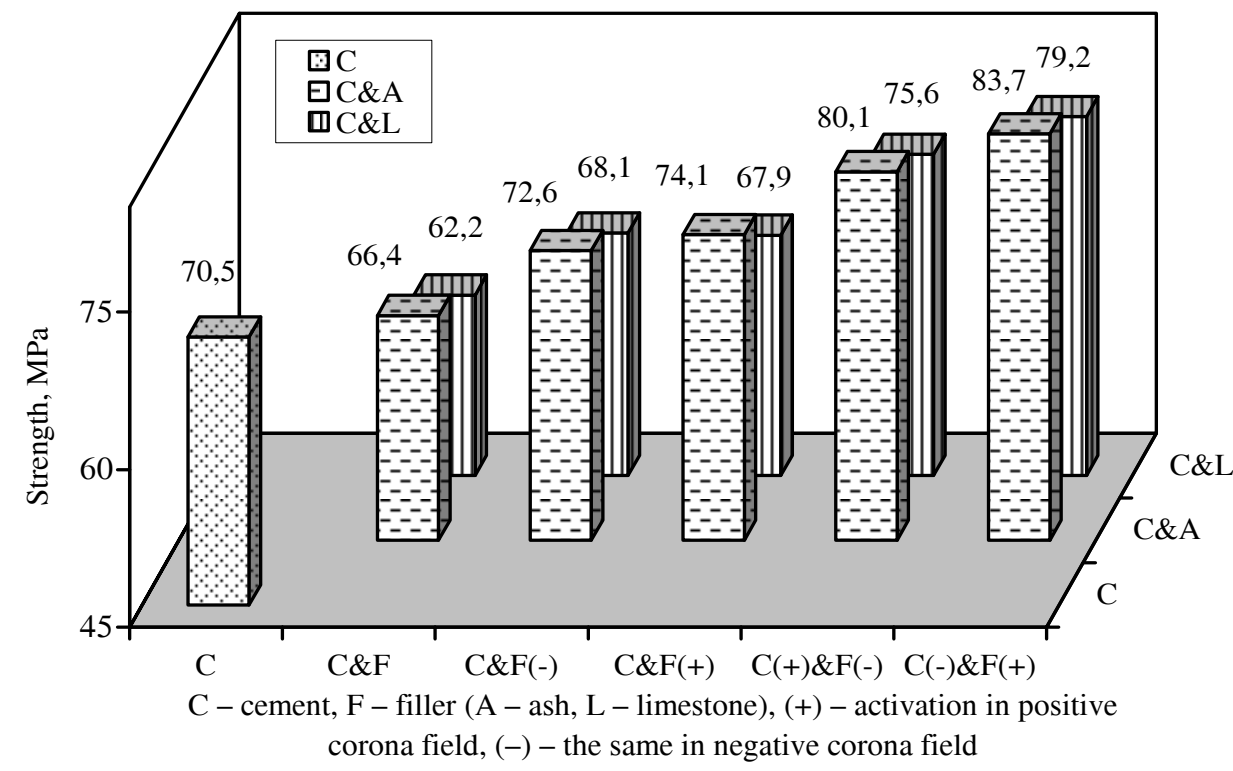

Fig 7. Compressive strength of concrete

ultimate compressive strength the standards-cubes with the rib size of $0,05 \mathrm{~m}$ were made. Compositions of concrete mixtures are given in Table 2. The water/powder materials ratio was chosen from the condition of providing the identical concrete mixture workability (the cone running diameter within the limits $120-125 \mathrm{~mm}$ ). During moulding concrete mixtures were mechanically compacted. After $24 \mathrm{~h}$ the specimens were removed from the moulds and covered with plastic sheets. At the age of 28 days of normal hardening $\left(20-22^{\circ} \mathrm{C} / 90-96 \% \mathrm{RH}\right)$ the specimens were tested for the compressive strength (Fig 7).

The tests were conducted on six replicate specimens and the average values are represented. The relative error is in the range of $1,77-2,36 \%$ (at the confidence level $95 \%$ ). Variation coefficient does not exceed $2,25 \%$. It was established that, when fillers (fly-ash or limestone) are used in the concrete composition, the water demand of mixtures rises. Activating fillers in the electrostatic field is insignificantly reflected on the changes of index of water/powder materials ratio. At the same time, the bipolar treatment of concrete dispersed components provides the obtaining of uniquely mixtures in comparison with the control composition at the lower value of water/powder materials ratio $(0,25$ in comparison to 0,29$)$.
The partial replacement of Portland cement by filler in control composition (C) lowers strength characteristics of concrete: with addition of fly-ash - by $6 \%$, with addition of limestone - by $12 \%$. For all compositions with activated filler, in spite of the fact, that the water/cement ratio of mixtures practically remains unchanged, compressive strength of concrete rises. Probably, it is associated with the fact that the electric field of the filler charged particle, contacting with the cement granule, induces in it the opposite electric charge (mirror reflection) [19]. As a result of arising heterogeneous electric contacts, the strength of the system increases. This effect becomes apparent in a considerably greater degree when cement and filler are activated in the electrostatic field with the opposite polarity of the corona electrode. Compressive strength of concrete with addition of fly-ash, in comparison with control composition, rises by $19 \%$, with addition of limestone filler - by $12 \%$. In addition, the saving of Portland cement on $100 \mathrm{~kg} / \mathrm{m}^{3}(13,3 \%)$ has been achieved. At the same time when the concrete compositions are similar, the treatment of Portland cement and fillers in the electrostatic field with the opposite polarity of the corona electrode contributes the higher compressive strength by $26-27 \%$. It must be compared with reported earlier $15 \%$ [10]. 


\section{Conclusions}

1. The computer modelling of the corona-electrostatic field has allowed choosing the optimum parameters of the installation for activating the dispersed components of concrete.

2. High-voltage polarisation of Portland cement and fillers has a substantial influence on the interparticle interactions in cement pastes and concrete mixtures. As a result, the effective viscosity of concrete mixtures is decreased by $36-40 \%$.

3. The electrostatic processing of concrete mixture components in the installation designed with due regard for computer modelling has allowed to increase the concrete compressive strength by $26-27 \%$.

\section{References}

1. SABIR, B. B.; WILD, S.; BAI, J. Metakaolin and calcined clays as pozzolans for concrete: a review. Cement and Concrete Composites, 2001, 23(6), p. 441-454.

2. Review - Cement of yesterday and today. Concrete of tomorrow. Cement and Concrete Research, 2000, 30(9), p. 1349-1359.

3. FERRARIS, C. F.; OBLA, K. H.; HILL, R. The influence of mineral admixtures on the rheology of cement paste and concrete. Cement and Concrete Research, 2001, 31(2), p. 245-255.

4. NEHDI, M. Why some carbonate fillers cause rapid increases of viscosity in dispersed cement-based materials. Cement and Concrete Research, 2000, 30(10), p. 1663 1669.

5. MENENDEZ, G.; BONAVETTI, V.; IRASSAR, E. F. Strength development of ternary blended cement with limestone filler and blast-furnace slag. Cement and Concrete Composites, 2003, 25(1), p. 61-67.

6. LEE, C. Y.; LEE, H. K.; LEE, K. M. Strength and microstructural characteristics of chemically activated fly ashcement systems. Cement and Concrete Research, 2003, 33(3), p. 425-431.

7. SARASWATHY, V.; MURALIDHARAN, S.; THANGA VEL, K.; SRINIVASAN, S. Influence of activated fly ash on corrosion-resistance and strength of concrete. Cement and Concrete Composites, 2003, 25(7), p. 673-680.
8. VERESCHAGIN, V. I.; SILKINA, O. V. The effect of high-voltage corona discharge on the hydration of clinker minerals. Cement (Цемент), 1992, 1, p. 4-8 (in Russian).

9. MATVIYENKO, V. A.; ZAICHENKO, N. M. Hardening of Cements Polarized in Electrical Field. In Proc of the 10-th International Congress on the Chemistry of Cement, Sweden, 2-6 June 1997, p. 785-789.

10. Patent 2073362 Russian Federation, 6 C04B40/00 / Chelyabinsk state technical university - 20041227.

11. BOHM, J. Electrostatic precipitators. Elsevier, Amsterdam, 1982.

12. CARON, A.; DASCALESCU, L. Numerical modelling of combined corona-electrostatic fields. Journal of Electrostatics, 2004, 61(1), p. 43-55.

13. GUSEV, B. V.; BOLTRYK, M.; MALASHKEVICH, D. Viscosity and thixotropy of dispersed systems. Building materials, installation, technologies of the XXI century (Строительные материалы, оборудование, технологии XXI века), 2001, 6(29), p. 26-27 (in Russian).

14. MASLYAYEV, A. F. The features of determination of vibration viscosity coefficient of concrete mixture by ball viscosimeter. In Proc of the 42-nd International Seminar on Modelling and Optimization of Composites. Odessa, 24-25 April, 2003, p. 91 (in Russian).

15. TANAKA, I.; KOISHI, M.; SHINOHARA, K. A study on the process for formation of spherical cement through an examination of the changes of powder properties and electrical charges of the cement and its constituent materials during surface modification. Cement and Concrete Research, 2002, 32(1), p. 57-64.

16. Concrete admixture handbook. Properties, Science, and Technology. Ed by V. S. Ramachandran. Moscow: Stroyizdat, 1988. 575 p. (in Russian).

17. MATVIYENKO, V. A.; ZAICHENKO, N. M.; TOLCHIN, S. M. Electro-surface properties of aggregates from waste products and their influence on the quality of finegrained concrete. In Proc of the International Conference “Creating with concrete”, Dundee, 1999, p. 131-137.

18. BABUSHKIN, V. I. et al. The influence of electrosurface phenomena on the processes of hardening of cement paste and concrete. In Proc of 2-nd Russian Conference on concrete and reinforced concrete, Moscow, 5-9 Sept 2005, p. 19-23 (in Russian).

19. ZIMON, A. D.; ANDRIANOV, E. I. Autohesion of powder materials. Moscow: Metallurgy, 1978. 288 p. (in Russian).

\title{
ELEKTROSTATINĖS AKTYVACIJOS PARAMETRŲ İTAKA SMULKIAGRŪDŽIO BETONO REOLOGINĖMS IR MECHANINĖMS SAVYBĖMS
}

\author{
N. Zaichenko, N. Golodenko, A. Khalyushev
}

Santrauka

Pastaraisiais metais siekiant gauti aukšto stiprio betoną jo mišiniui gaminti naudojami cementą pakeičiantys priedai (kalkès ar pucolanai). Tačiau šių medžiagų naudojimas sukelia nepageidaujamus efektus. Naudojant kalkes greiteja hidratacijos reakcija ankstyvajame amžiuje. Be to, dèl dilantiškumo efekto gali sumažėti betono stiprumas. Pelenai padidina betono stiprumą tik vèlesniame amžiuje. Šiai problemai spręsti pasiūlytas Portland cemento ir priedų elektrostatinès aktyvacijos metodas. Parinkus optimalius aktyvacijos parametrus, betono reologinès ir mechaninès savybės pagerèja.

Reikšminiai žodžiai: aktyvacija, elektrostatinis laukas, betonas, klampumas, gniuždomasis stipris, pelenai, kalkès.

Nickolay ZAICHENKO. PhD, Candidate for Doctor's degree, Assoc Prof of technologies of building materials, products and automobile roads. Dept of Donbass National Academy of Civil Engineering and Architecture, Makeyevka, Ukraine. High-strength and high-performance concretes on the base of physical-chemical modified fillers is the sphere of his research activity. 
Nickolay GOLODENKO. PhD, Assoc Prof of physics, Dept at Donbass National Academy of Civil Engineering and Architecture, Makeyevka, Ukraine. His main research interests include computer modelling of physics processes.

Alexander KHALYUSHEV. Post-graduate student of technologies of building materials, products and automobile roads. Dept of Donbass National Academy of Civil Engineering and Architecture, Makeyevka, Ukraine. Sphere of scientific activity - fine-grained concretes on the basis of composed cements. 